ARH-2401

UC-4I, Health and Safety

(TID 4500, 59th Ea.)

\title{
MOBILITY OF PLUTONIUM COMPOUNDS \\ IN SIMULATED FIRE SPRINKLER SPRAY
}

By

J. Vincent Panesko

Chemical Technology Laboratory

Research and Development

Chemical Processing Division

October 1972

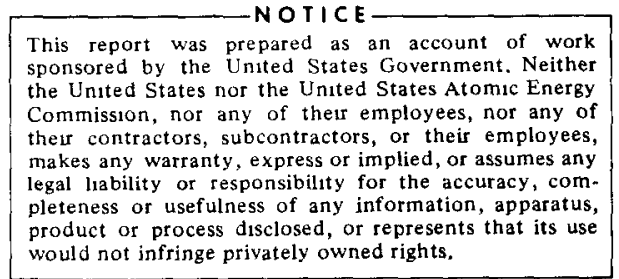

ATLANTIC RICHFIELD HANFORD COMPANY

RICHLAND, WASHINGTON

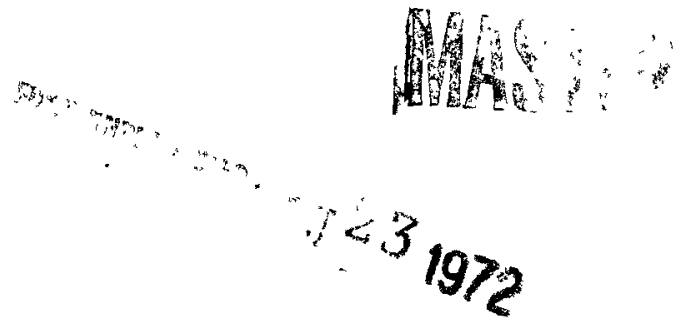

DISTRIBUTION OF THIS DOCUMENT IS URLIMITFD 


\section{DISCLAIMER}

This report was prepared as an account of work sponsored by an agency of the United States Government. Neither the United States Government nor any agency Thereof, nor any of their employees, makes any warranty, express or implied, or assumes any legal liability or responsibility for the accuracy, completeness, or usefulness of any information, apparatus, product, or process disclosed, or represents that its use would not infringe privately owned rights. Reference herein to any specific commercial product, process, or service by trade name, trademark, manufacturer, or otherwise does not necessarily constitute or imply its endorsement, recommendation, or favoring by the United States Government or any agency thereof. The views and opinions of authors expressed herein do not necessarily state or reflect those of the United States Government or any agency thereof. 


\section{DISCLAIMER}

Portions of this document may be illegible in electronic image products. Images are produced from the best available original document. 


\section{$\underline{\text { Page }}$}

ABSTRACT . . . . . . . . . . . . . . . . . . . .

INTRODUCTION $\cdot \cdot \cdot \cdot \cdot \cdot \cdot \cdot \cdot \cdot \cdot \cdot \cdot \cdot \cdot \cdot \cdot \cdot \cdot \cdot \cdot \cdot \cdot$

SUMMARY • . . . . . . . . . . . . . . . . . . . 1

EXPERIMENTAL . . . . . . . . . . . . . . . . . . . . . . 2

PRE-EXPERIMENTAL OBSERVATIONS • • • • . • . . . 2

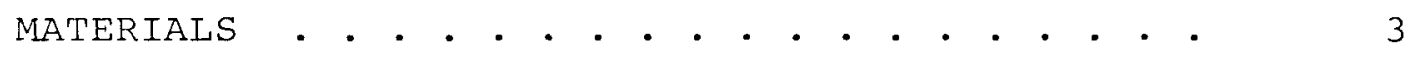

EXPERIMENTAL PROCEDURES . . . . . . . . . . .

RESULTS . . . . . . . . . . . . . . . . . . . . 4

WATER SPRAY ON PLUTONIUM NITRATE . . . . . . . . . 4

WATER SPRAY ON PLUTONIUM OXIDE • • • • • • • • • . 6

WATER SPRAY ON PLUTONIUM FLUORIDE • • • • . . . . .

PLUTONIUM NITRATE INTO SUMP SOLUTION . . . . . . 10

PLUTONIUM OXIDE INTO WATER . • . • . • . . . . . 10

PLUTONIUM FLUORIDE INTO WATER • • . • • • . • . 13

ACKNOWLEDGMENTS . . . . . . . . . . . . . . . . . . . 13

REFERENCES . . . . . . . . . . . . . . . . . . 15 


\section{ABSTRACT}

Water spray formed a protective layer of water over more-dense plutonium compounds. Dry plutonium compounds immediately settred to the bottom of a layer of water. Plutonium nitrate rapialy diffused throughout sump solution. 


\section{MOBILITY OF PLUTONIUM COMPOUNDS \\ IN SIMULATED FIRE SPRINKLER SPRAY}

\section{INTRODUCTION}

The installation of fire sprinklers in rooms where large quantities of plutonium are processed created a remote possibility that water spray might contact plutonium. [1] Water would have to breach Lucite ceiling panels in glove boxes to contact plutonium powders. [2] In other circumstances water would enter a shipping container if a fire sprinkler were set off above an open container during solution transfer. [3] Containers of plutonium powder might tip over into fire sprinkler water. Plutonium nitrate solutions from ruptured tanks might eventually drain into sump tanks. [4] The following report describes what happened when water and plutonium were contacted in the above-assumed situations.

\section{SUMMARY}

The application of water to plutonium nitrate, oxide, or fluoride replaced a portion of plutonium with a layer of water which acted as a protective barrier for the remaining, more-dense plutonium. The degree of protection depended on the force of the impinging water, the thickness of the water layer, and the density of the plutonium. Fire sprinklers generated fine mist with very little impact force; thus less than 1/2" of water would protect typical plutonium nitrate, oxide, or fluoride. A "worst case" would occur if the ceiling panel of a glove box began to leak, yielding a steady stream of large water drops. In such a case a layer of water between one and two inches deep accumulated before the action 
of the impinging stream was buffered enough to prevent agitation of the underlying plutonium-bearing material. The small amount of solids which were washed out settled evenly over the floor, whereafter a protective layer of water prevented further movement.

Plutonium oxide and fluoride immediately settled through a water layer without observable surface tension effects. Fines were dispersed throughout the lower portion of the solution; fluoride fines settled out in minutes while oxide fines settled out in several hours. In each case the fines were only a small fraction of the powder introduced into the solution.

Plutonium nitrate quickly dispersed in sump solution beginning at the point of entry and increasing with the depth of penetration. Self-generated mixing currents yielded essentially complete dispersion in one minute.

\section{EXPER IMENTAL}

\section{PRE-EXPERIMENTAL OBSERVATIONS}

Observations of a fire sprinkler in operation revealed that the spray could be more accurately described as "mist." An impinger plate broke the water into small particles which floated downward without significant force. Thus a fire sprinkler mist could be easily simulated in the laboratory by a nonforceful application of water. In another demonstration water was allowed to accumulate on a plate wire glass hood panel which had been exposed to high temperatures. Water leaked through cracks in the glass and formed very large drops which fell from the underside of the panel. These large drops possessed a great deal more force upon impact than did fire sprinkler mist. Thus the concept was developed that 
while mist itself possessed insignificant impact force, it could accumulate on surfaces and form large drops which possessed much greater impact force. A worst case occurred when several inches of water had accumulated on top of the glove box panel and a rapid stream of large water drops was falling into the box. Water leakage through a glove box ceiling could be simulated in the laboratory by releasing drops of water from a given height.

\section{MATERIALS}

Plutonium used in this study was obtained from Hanford production facilities. The plutonium nitrate used in the water spray study contained $136 \mathrm{~g} / 1$ iter plutonium with a specific gravity of 1.35. The plutonium nitrates aropped into sump solution were 50 and $320 \mathrm{~g} / \mathrm{liter}$ plutonium in $2 \mathrm{M}$ nitric acid. Densities of plutonium oxide and fluoride were 1.9 and $1.4 \mathrm{~g} / \mathrm{cc}$, respectively, while percents plutonium were 86 and 76 , respectively.

\section{EXPERIMENTAL PROCEDURES}

Water was dropped from a height of $30 "$ into $45 \mathrm{milli-}$ liters of plutonium nitrate contained in a 50-milliliter centrifuge cone which approximated the diameter:height ratio of some shipping containers. Between 200 and 300 milliliters of water were added in a 3-minute period.

Water was also dropped into 50-milliliters beakers containing 30 or 42 milliliters of $\mathrm{PuO}_{2}$ or 45 milliliters of $\mathrm{PuF}_{4}$. In each case approximately one liter of water was added in a 3-minute period. The water was dropped from a plastic bottle with sufficient holes in the bottom to allow water to collect into large drops before falling.

Plutonium oxide and fluoride were dropped from a height 
of 6" into 1 liter of water. About 30 milliliters of each powder were used. Two plutonium nitrate solutions were each dropped at a rate of $10 \mathrm{ml} / \mathrm{min}$ into 1 liter of sump solution contained in a two-liter beaker. This represented plutonium being added at a $26 \mathrm{gal} / \mathrm{min}$ flow rate into the $10-\mathrm{ft}$ diam, 8-ft high sump tank half-full of solution.

\section{RESULTS}

WATER SPRAY ON PLUTONIUM NITRATE

The initial contact of water diluted the upper portion of plutonium nitrate. As seen in Photographs 2 and 3, Figure 1, the upper 1 " of solution was almost as dark as the undisturbed plutonium nitrate lower in the centrifuge cone. After an inch of water accumulated, water droplets penetrated only about $1 / 2 "$ into the water layer and did not agitate the underlying plutonium. As seen in Photographs 4 and 5, Figure 1, there was a distinct boundary between the clear water layer and the undisturbed dark plutonium nitrate. Water droplets can be seen only partially penetrating the water layer. Thus the layer of water acted as a barrier which adsorbed the momentum of falling droplets and protected the underlying plutonium from agitation. Obviously with fire sprinkler mist only lightly falling on the surface, there would be much less initial disturbance of the plutonium nitrate than observed in these photographs.

Photograph 6 was taken an hour after the 3-minute sprinkler period ended. A comparison of Photographs 1 and 6 showed that only 3 milliliters of plutonium nitrate had been removed, mostly in the initial few seconds where there had been a great deal of agitation of the surface.

Diffusion of plutonium into the upper water layer was 
\#1

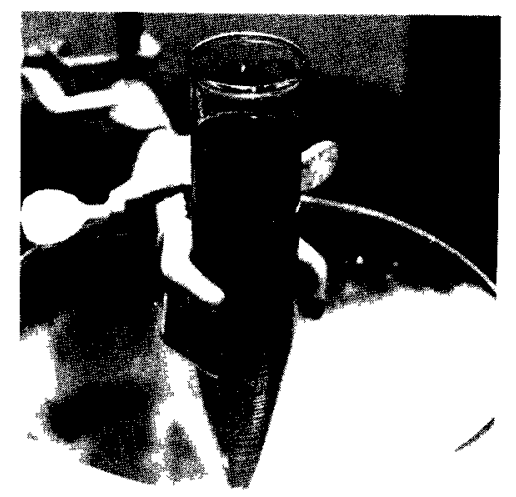

$t=0$

\# 3

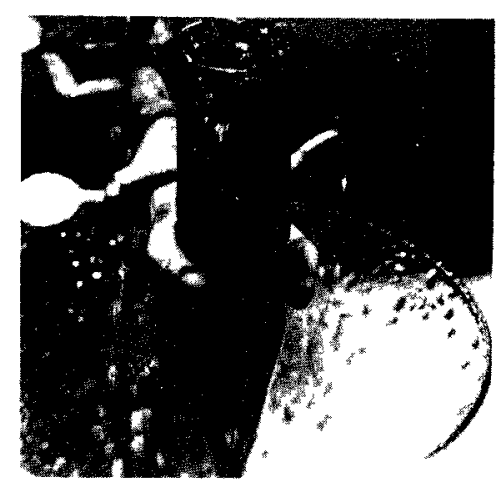

$t=10 \mathrm{sec}$

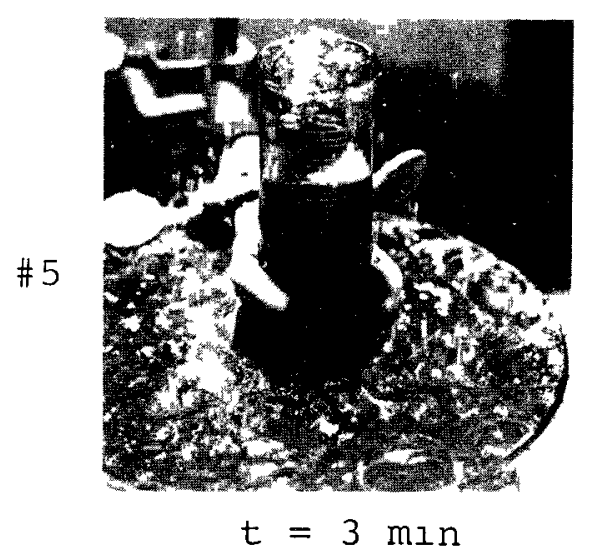

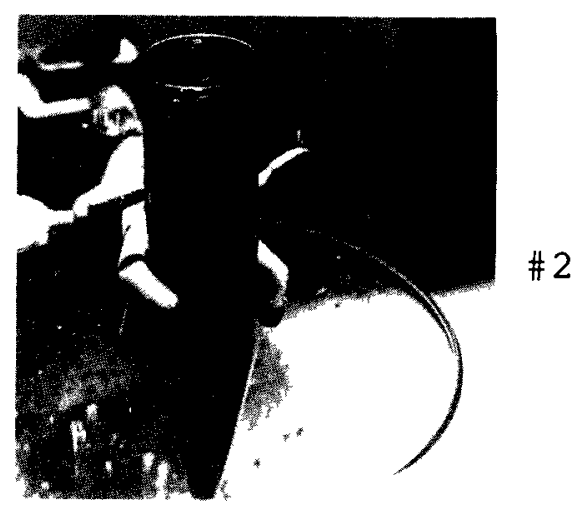

$t=3 \mathrm{sec}$

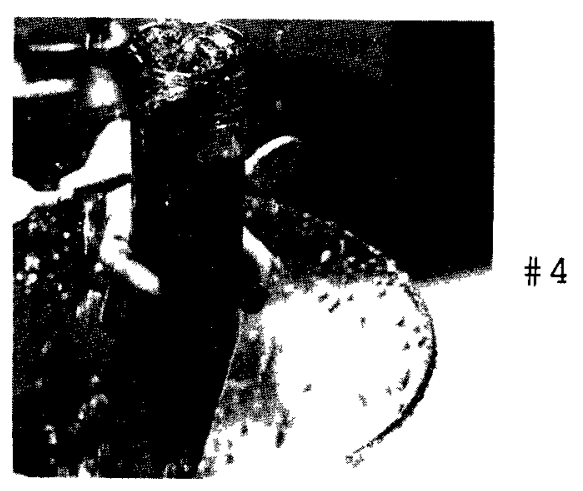

$t=1 \mathrm{~min}$

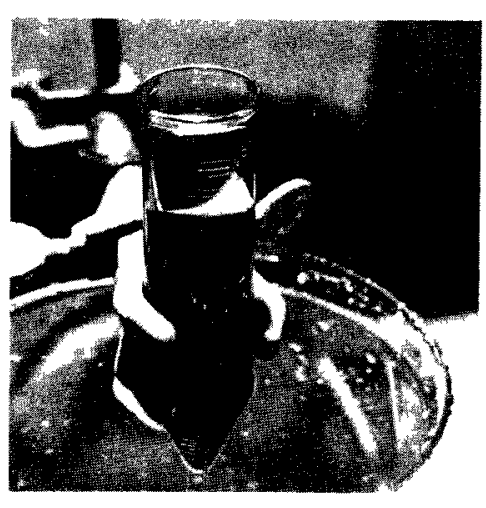

$t=63 \mathrm{~min}$

FIGURE 1

WATER SPRAY ON PLUTONIUM NITRATE 
surprisingly slow. After one hour the water layer (Photograph 6) was clear with plutonium diffusion less than 1/16" into the water layer. Plutonium polymer was not observed because acid diffusion into the water layer was faster than plutonium diffusion; therefore plutonium was always in an acidic matrix.

WATER SPRAY ON PLUTONIUM OXIDE

Preliminary tests with 30-miliiliter amounts of plutonium oxide demonstrated that the mobility of plutonium depended on the force of the impinging water. In all cases the initial contact of water with oxide resulted in spattering. Within a few seconds a mud formed after which water accumulation on top of the oxide increased faster than water sorption into the oxide. Once the water layer had reached a depth of $1 / 4$ to $1 / 2 "$, underlying oxide was undisturbed by small drops of low-impact water. Greater depths of water were required to provide complete protection from higherpressure water streams. For example, a water stream under pressure from a hand-held squeeze bottle could penetrate a 1-1/4" layer of water and agitate plutonium oxide fines.

Another observation was the rather slow rate of water sorption into the oxide. In a test where $30 \mathrm{milliliters}$ of water were added to 33 milliliters of dry oxide in a 50milliliter beaker, only 10 milliliters of water were sorbed in 5 minutes; and 15 milliliters were sorbed after 15 minutes.

Figure 2 shows the contact of water with 42 milliliters of plutonium oxide. Photograph 8 shows the spattering and mud phase during the first seconds of contact. Oxide was removed from the beaker and was visible in the white plastic pan surrounding the beaker. Photograph 9 shows the agitation 

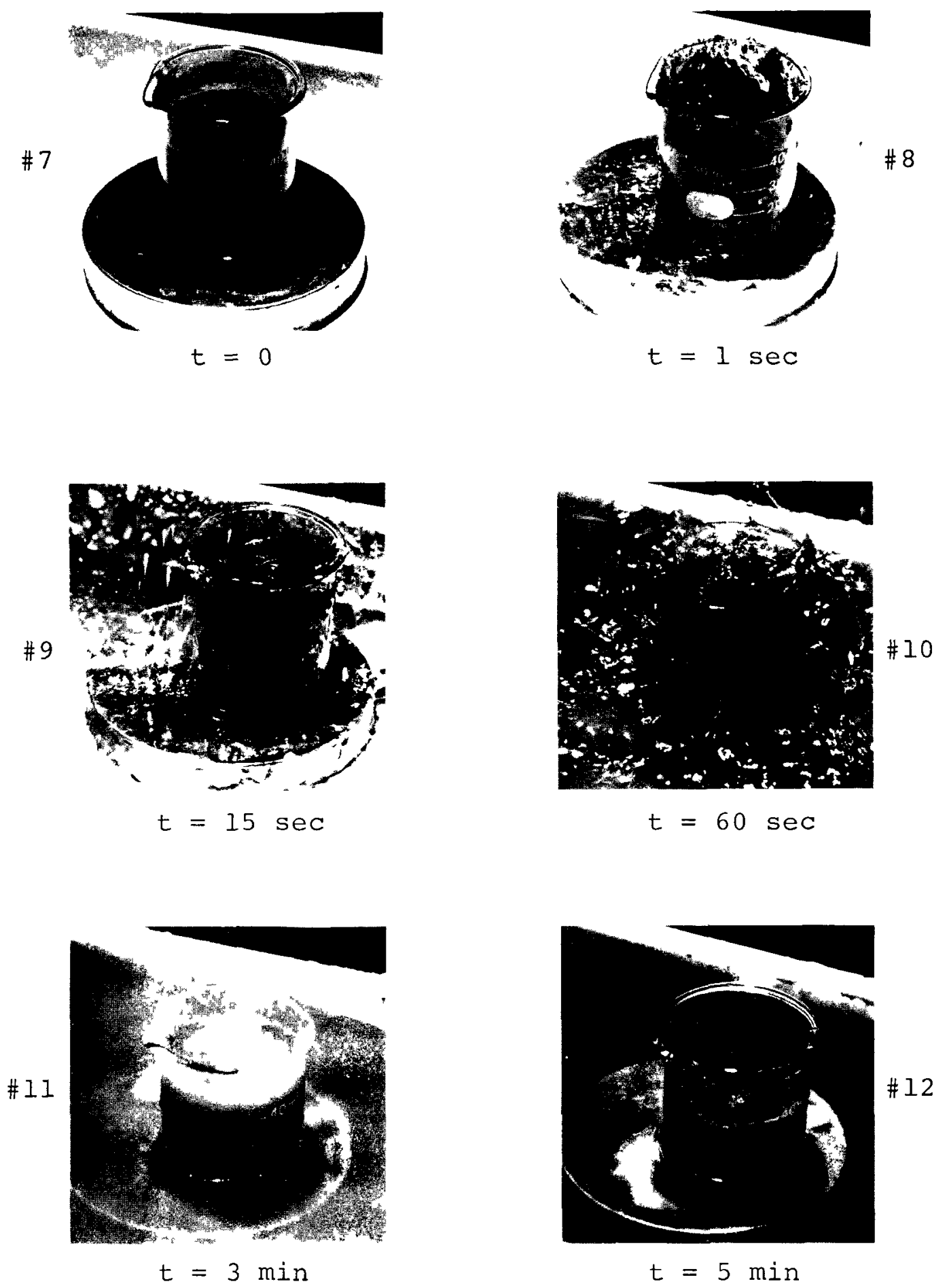

FIGURE 2

WATER SPRAY ON PLUTONIUM OXIDE 
which occurred 15 seconds after the start of the experiment. The solution was a dark, thick suspension of oxide below which dry powder was visible.

The solution overflowing and being splashed out of the beaker in Photograph 10 was noticeably lighter than the solution viewed in Photograph 9. This latter solution contained only fines which diminished as more water was added. An even coating of oxide fines can be seen over the entire surface of the pan. Most of the fines settled out rapidly although there were enough in suspension to block from view the tin lid supporting the beaker.

Photograph 11 shows the oxide after water had been applied at a rate of 15 to $18 \mathrm{ml} / \mathrm{min} / \mathrm{cm}^{2}$ for 3 minutes. only five milliliters of powder had been removed. Moisture sorbed into the oxide, forming a layer about 1/2" thick below which the oxide appeared dry. The uneven line separating the wet and dry oxide was visible near the 30-milliliter mark.

One reason for so little plutonium oxide removal may have been a mechanism whereby water caused the powder to form lumps. This possibility was suggested by Photograph 12 in Figure 2. The oxide was powder-fine when placed into the beaker, but aggregates of oxide are clearly visible after treatment with water. These lumps may have assisted in holding down the oxide, allowing only a small amount of fines to be suspended.

\section{WATER SPRAY ON PLUTONIUM FLUORIDE}

The application of water to plutonium fluoride yielded results generally similar to the oxide experiment. The spattering and mud phase during the first few seconds of the contact are shown in Photograph 14, Figure 3. The fluoride 

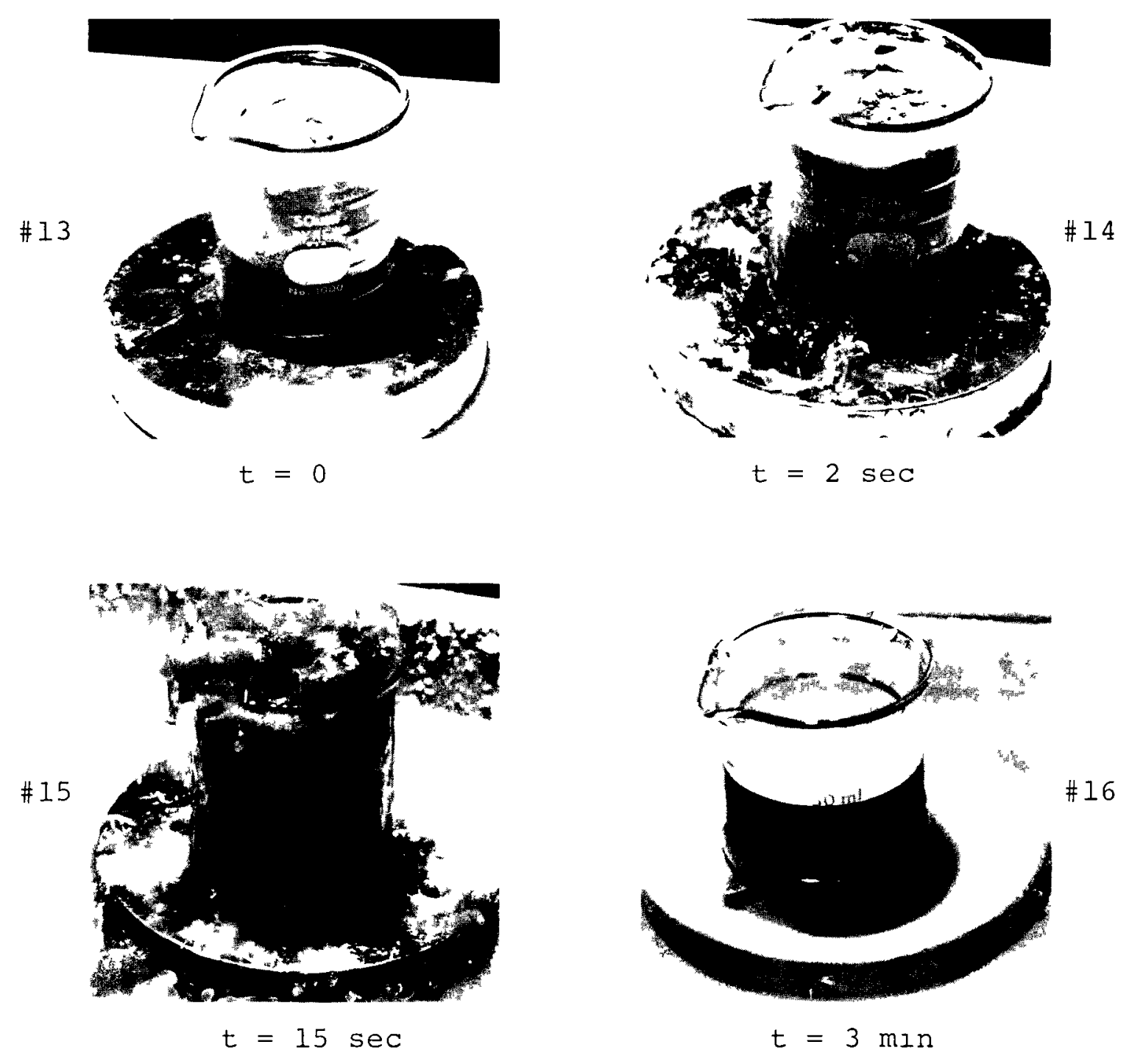

FIGURE 3

WATER SPRAY ON PLUTONIUM FLUORIDE 
appeared finer than the oxide in Figure 2; the fluoride tended to form a cake. This was more evident in Photograph 16 which shows a fluoride-water interface much smoother than the lumps which formed at the oxide-water interface.

Once the water level had increased to between 1 and 1 1/2" there was little disturbance of the underlying powder. The water solution above the powder was somewhat opaque, but only 10 milliliters of solids were removed in a three-minute period.

\section{PLUTONIUM NITRATE INTO SUMP SOLUTION}

Plutonium nitrate containing about $50 \mathrm{~g} / \mathrm{liter}$ plutonium immediately dispersed when dropped into sump solution (see Figure 4). Photograph 17 shows that dispersion occurred along the entire length of the trail of plutonium nitrate. The nitrate reached the bottom and formed a uniform dispersion which spread over the floor of the beaker. As more nitrate was added the uniform dispersion spread upward so that at 60 seconds the plutonium nitrate appeared to be dispersed throughout most of the beaker (Photograph 19).

The addition of $300 \mathrm{~g} /$ liter plutonium nitrate to a fresh liter of sump solution yielded rapid dispersion beginning in the bottom of the beaker and moving upward (see Photographs 20 and 21). After 60 seconds plutonium nitrate had almost dispersed throughout the entire beaker (see Photograph 22).

\section{PLUTONIUM OXIDE AND WATER}

Plutonium oxide aropped into water immediately settled to the bottom except for fines which formed a suspension requiring hours to settle out (Figure 5). Photograph 23, Figure 5, shows oxide falling through water. Five seconds 
11

ARH -2401

$\# 17$
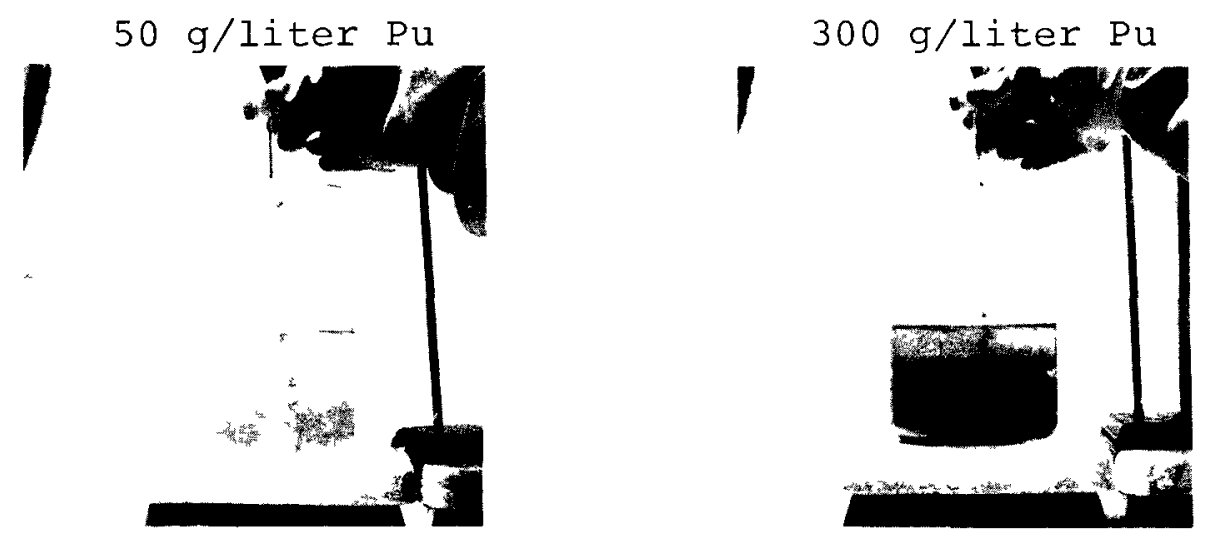

$t=10 \mathrm{sec}$

$$
t=10 \mathrm{sec}
$$

\#20
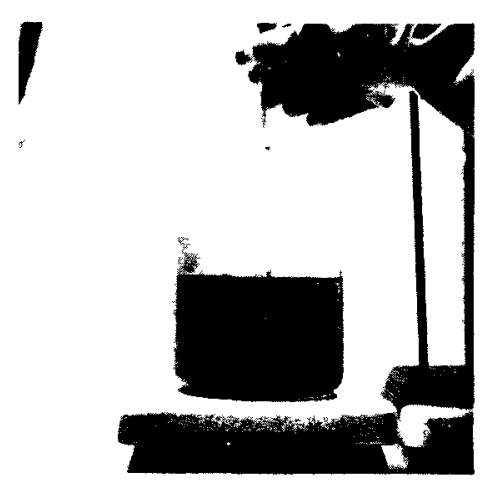

\#21

\#18

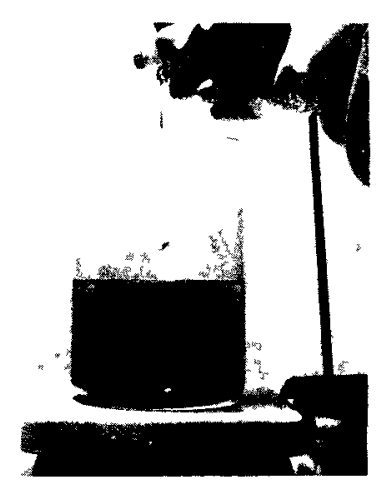

$t=30 \mathrm{sec}$

\#19

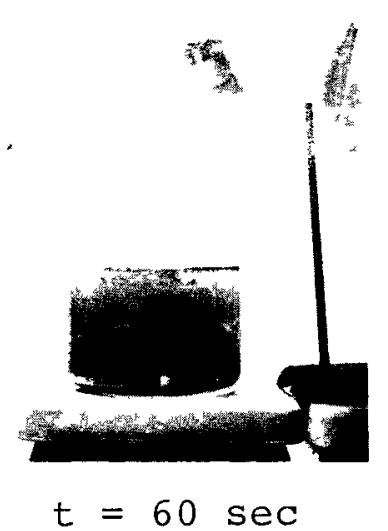

I

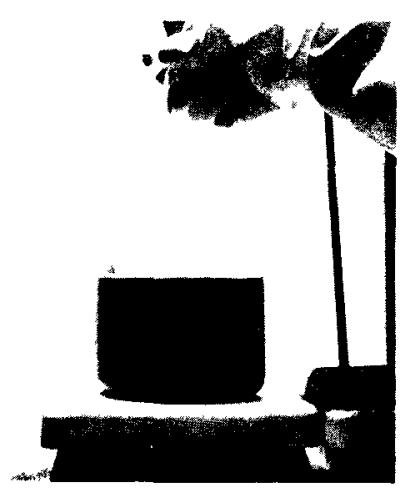

$\# 22$

$t=60 \mathrm{sec}$

FIGURE 4

PLUTONIUM NITRATE INTO SUMP SOLUTION 

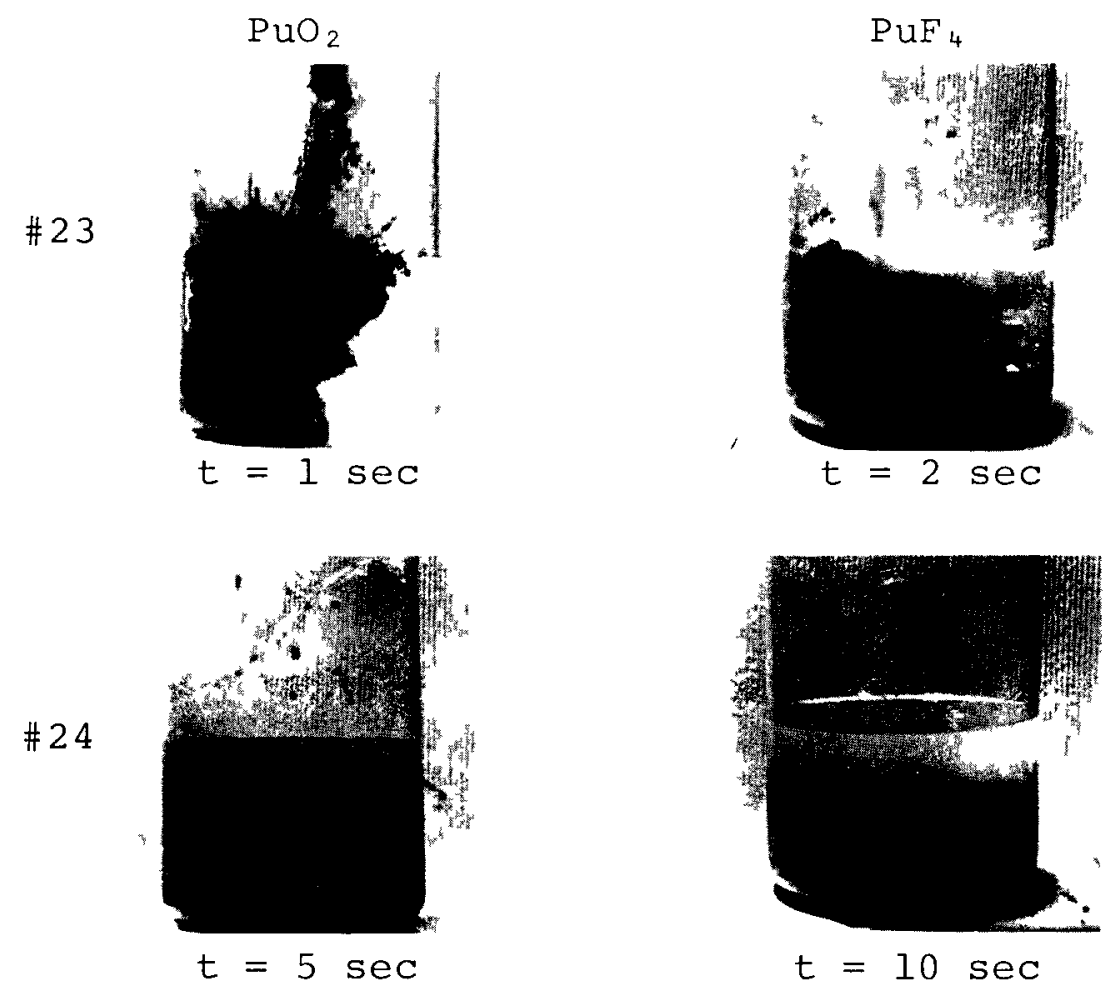

$\# 28$
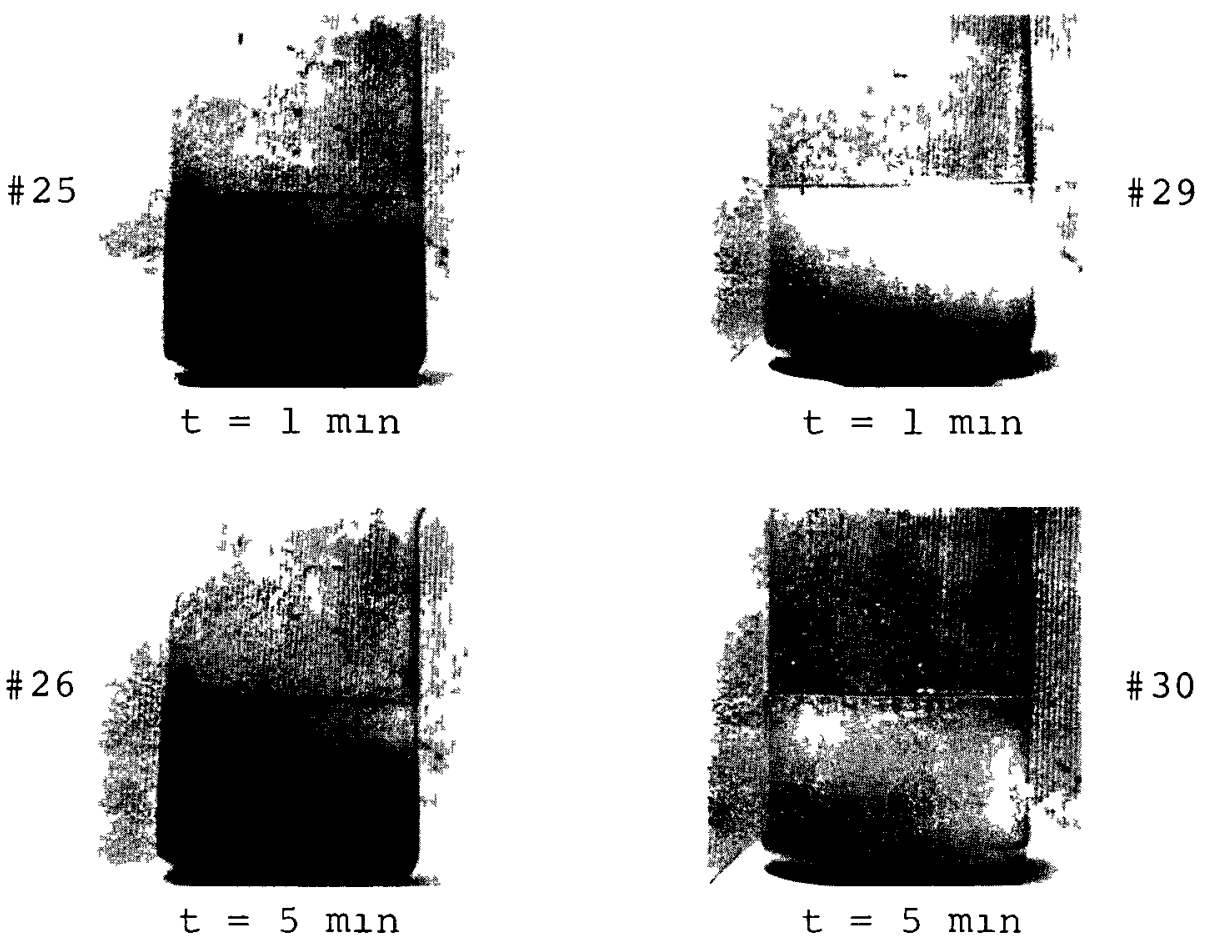

FIGURE 5

PLUTONIUM OXIDE AND FLUORIDE IN WATER 
later, fines were suspended throughout the entire volume; although most of the oxide was on the bottom (Photograph 24). After five minutes most of the fines remained suspended (Photographs 25 and 26). After 24 hours there were oxide fines remaining in suspension, but well below the surface of the water.

PLUTONIUM FLUORIDE INTO WATER

Plutonium fluoride, like oxide, dropped directly to the bottom of the beaker; fines mushroomed out and raised a suspension of fines upward (see Photograph 27, Figure 5). Most of the fines had settled out after one minute (Photograph 29). Only a small trace of fines remained suspended after five minutes (Photograph 30).

Another study with small amounts of fluoride is shown in Figure 6. Photograph 31 shows the addition of 2 milliliters of plutonium fluoride to water. The fluoride settled to the bottom without visible surface tension effects on the water-air interface. Dispersion of fines occurred, but as Photograph 32 shows, the dispersed fluoride settled out in one minute, leaving particles of fluoride on the bottom of the beaker. Photographs 33, 34, and 35 show the initial dispersion of $5 \mathrm{milliliters}$ of fluoride and the rather rapid settling at 30 and $60 \mathrm{sec}$, respectively.

\section{ACKNOWLEDGMENTS}

K. R. Ridgway defined the scope and assisted in the design of these experiments. W. A. Blyckert assisted in the design and recorded the water spray experiments on videotape. Appreciation is expressed to $\mathrm{H}$. A. Lee for the demonstration of fire sprinklers and water leakage through hood ceiling panels. Appreciation is also expressed to M. H. Campbell 


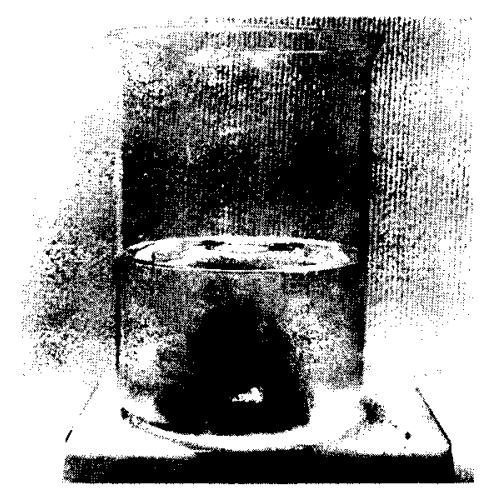

$t=1 \mathrm{sec}$

\# 32

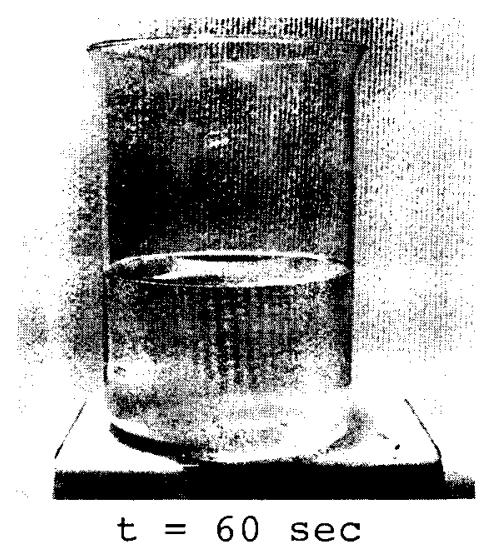

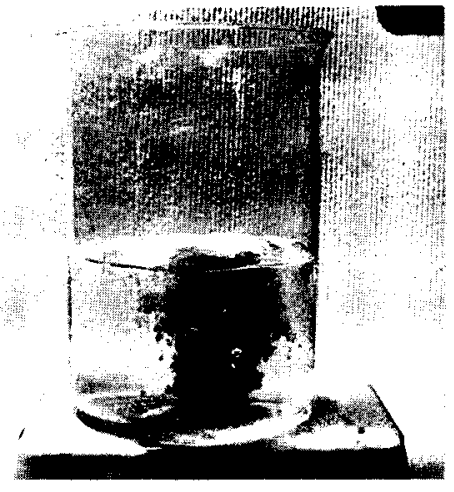

$t=1 \mathrm{sec}$

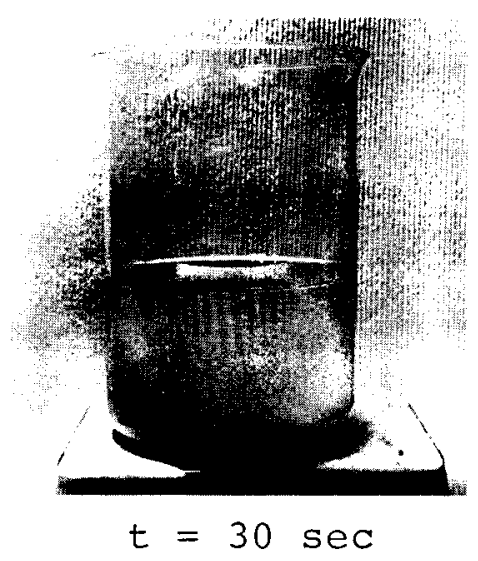

$\# 34$

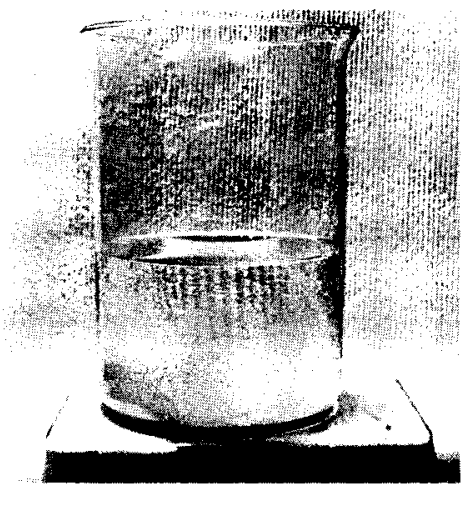

$\# 35$

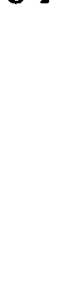

\section{FIGURE 6}


for editorial assistance and to Eleanore Earhart for secretarial assistance.

\section{REFERENCES}

1. W. A. Blyckert, R. D. Carter, and K. R. Ridgway, Redefined Criticality Risk Categories for Fire Safety, ARH-2468, Atlantic Richfield Hanford Company, Richland, Washington, February 10, 1972.

2. W. A. Blyckert, Personal Communication, Atlantic Richfield Hanford Company, Richland, Washington, January 1972 .

3. K. R. Ridgway, Personal Communication, Atlantic Richfield Hanford Company, Richland, Washington, February 1972.

4. K. R. Ridgway, Personal Communication, Atlantic Richfield Hanford Company, Richland, Washington, July 1972. 


\section{DISTRIBUTION}

Number of Copies

261

10
Atlantic Richfield Hanford Company

G. E. Backman

W. A. Blyckert

I. I. Brecke

M. H. Campbell (5)

R. D. Carter

R. P. Corlew

M. H. Curtis

J. B. Fecht

R. E. Felt

R. D. Fox

W. P. Ingalis

R. E. Isaacson

J. W. Jordan

L. M. Knights

H. A. Lee

A. J. Low

D. C. Nelson

R. E. Olson

J. V. Panesko (10)

L. M. Richards

A. E. Smith

P. W. Smith

R. W. Szempruch

J. A. Teal

J. H. Warren

G. W. Upington

ARHCO Document Services (3)

Extra (15)

Atomic Energy Commission Technical Information Center, Oak Ridge, Tennessee

Atomic Energy Commission, Richland Operations Office

O. J. Elgert

Battelle Memorial Institute, Pacific

Northwest Laboratory

C. L. Brown

D. E. Clayton 
Number of Copies

2

Westinghouse Hanford Company

J. K. Anderson

J. B. Edgar 